\title{
Analisis Profitabilitas Pada PT Bank Negara Indonesia Tbk Cabang Manado
}

\author{
Nathalia A. Chandra \\ Joula J. Rogahang \\ Dantje Keles \\ Jurusan Ilmu Administrasi, Program Studi Administrasi Bisnis \\ Fakultas Ilmu Sosial dan Politik, Universitas Sam Ratulangi \\ nathaliaangrena.na@gmail.com
}

\begin{abstract}
The purpose of this research is to analyze the financial ratios in particular the profitability ratio of PT Bank Negara Indonesia Tbk. In the present era more and more companies are emerging and also the competition is so strict, therefore the company must Increase the profit that can be able to compete. The research method used is the ratio of profitability. The profitability ratio is a ratio used to measure the company's ability to generate profit at a certain level of sales, Aser, and stock Capital The research results show that profitability can be said to be good when Profit that can be held annually in the company is able to achieve the target of the company itself. And the results obtained from the research of each indicator for five years from year 2014-2018 is as follows. Gross Profit Margin in the year 2014 of 59\%, 2015 of 45\%, 2016 amounted to 48\%, 2017 for 54\%, and 2018 for 56\%. Operating Profit Margin in the year 2014 of 59\%, 2015 of 45\%, 2016 amounted to 48\%, 2017 for 54\%, and 2018 for 55\%. Net Profit Margin in the year 2014 of 48\%, 2015 of 36\%, 2016 amounted to 38\%, 2017 for 43\%, and 2018 for $42 \%$. Return on Assets in 2014 amounted to 3\%, 2015 by 2\%, 2016 by 2\%, 2017 by 2\%, and 2018 by $2 \%$. Return on Equity in 2014 amounted to 18\%, 2015 by 12\%, 2016 by 13\%, 2017 by 14\%, and 2018 by $14 \%$. It can be seen from the presentation of the five indicators can be said to be good, although the presentation that can be in the company in 2015 was decreased, but the company was able to increase back in the following years. It means the company is able to minimize the profit gained according to expectations.
\end{abstract}

\section{Keywords: Financial Report, Profitability Ratio.}

\section{Pendahuluan}

Bank adalah sebuah perusahaan yang memiliki fungsi menghimpun dana, menyalurkan, dan memberikan pelayanan berupa jasa-jasa untuk masyarakat. Bank juga berperan sangat penting dalam kehidupan di masyarakat pada jaman sekarang ini, dimana setiap masyarakat pasti menggunakan jasa-jasa pada bank dalam menyimpan uang, meminjam uang dan lain-lain. Tujuan operasional semua perusahaan yaitu untuk memaksimalkan profit dalam jangka yang panjang maupun jangka pendek. Profit yang semakin baik akan berpengaruh baik pula terhadap perusahaannya juga.

Setiap perusahaan perbankan juga perlu diketahui tingkat kesehatan banknya. Salah satunya yaitu tingkat kesehatan dalam profitabilitas. Profitabilitas adalah 
sebuah alat analisis yang digunakan untuk mengukur tingkat keuntungan yang didapat perusahaan. maka dari itu rasio profitabilitas sangat penting untuk diteliti, Untuk itu dengan ditelitinya dalam segi profitabilitas dapat membantu perbankan menjalankan fungsinya bagi masyarakat dan juga untuk kemajuan industri perbankan di negaranya sendiri.

Dilihat dari laporan keuangan pada Bank Negara Indonesia, pada tahun 2015 presentase proftabilitas yang menurun dikarenakan laba yang menurun diakibatkan pembentukan cadangan kerugian penurunan nilai yang sangat naik drastis. Salah satu bank yang terkenal di kalangan masyarakat dari berbagai perusahaan industri perbankan yang berada di Indonesia adalah Bank Negara Indonesia Tbk. Maka dari itu masalah yang akan diteliti adalah bagaimana perkembangan profitabilitas bank dan apakah bank memiliki profitabilitas yang baik dan dalam lima tahun terakhir dilhat dari laporan keuangan Bank Negara Indonesia Tbk.

\section{Fungsi Bank}

a. Fungsi pembangunan (development). Tugas bank sebagai penghimpun dan penyalur dana sangat menunjang pertumbuhan perekonomian negara.

b. Fungsi pelayanan (service). Perbankan adalah jenis perusahaan dengan kegiatan yang berupa pemberian semua jasa yang dibutuhkan nasabah, baik dalam menyimpan maupun peminjam dana.

c. Fungsi Transmisi. Fungsi ini merupakam kegiatan perbankan yang berkaitan dengan lalu lintas pembayaran dan peredaran uang dengan menciptakan instrumen keuangan yang disebut denga uang giral.

\section{Tujuan Bank}

Tujuan Bank dijelaskan dalam pasal 3 UU No. 10 Tahun 1998 tentang perbankan : Perbankan Indonesia bertujuan menunjang pelaksanaan pembangunan nasional dalam rangka meningkatkan pemerataan, pertumbuhan ekonomi, dan stabilitas nasional ke arah peningkatan kesejahteraan rakyat banyak

\section{Laporan Keuangan}

Menurut Kasmir (2016:7), pengertian laporan keuangan adalah Laporan yang menunjukkan kondisi keuangan perusahaan pada saat ini atau dalam suatu periode tertentu.

\section{Jenis-Jenis Laporan Keuangan}

1. Neraca. Menurut Munawir (2010:13), neraca adalah laporan yang sistematis tentang aktiva, hutang serta modal dari suatu perusahaan pada suatu saat tertentu. 
2. Laporan Laba Rugi. Menurut Munawir (2010:26), Laporan laba rugi merupakan suatu laporan yang sistematis tentang penghasilan, biaya, rugi laba yang diperoleh oleh suatu perusahaan selama periode tertentu.

\section{Analisis Laporan Keuangan}

Menurut Munawir (2010:35), analisis laporan keuangan adalah Analisis laporan keuangan yang terdiri dari penelaahan atau mempelajari dari pada hubungan dan tendensi atau kecenderungan (trend) untuk menentukan posisi keuangan dan hasil operasi serta perkembangan perusahaan yang bersangkutan.

\section{Rasio Profitabilitas}

Rasio profitabilitas merupakan rasio yang digunakan untuk mengukur kemampuan perusahaan dalam menghasilkan laba dari aktivitas normal bisnisnya. Menurut Hanafi (2010:42) Rasio profitabilitas yaitu rasio yang digunakan perusahaan untuk mengukur kemampuan perusahaan menghasilkan keuntungan pada tingkat penjualan, aset, dan modal saham tertentu.

\section{Metode Penelitian}

Jenis penelitian yang digunakan oleh penulis ialah pendekatan deskriptif Kuantitatif. Menurut Sugiyono (2003) penelitian deskriptif adalah penelitian yang dilakukan untuk mengetahui nilai variable mandiri, baik satu variable atau lebih (independen) tanpa membuat perbandingan atau menghubungkan dengan variable yang lain. Penelitian kuantitatif adalah penelitian dengan memperoleh data yang berbentuk angka atau data kualitatif yang diangkakan.

Jenis data yang digunakan dalam penelitian ini adalah data sekunder yaitu data yang diterbitkan yang kemudian diolah menggunakan alat-alat analisis yang ada.

Proses pengumpulan data yang diperlukan adalah dokumentasi dan studi kepustakaan serta kajian literatur.

Data yang dikumpulkan kemudian dianalisis menggunakan alat analisis rasio keuangan yaitu rasio profitabiltas.

\section{Hasil Penelitian}

Tabel 1. Deskripsi Data Gross Profit Margin (GPM) terhadap Laporan Keuangan PT. Bank Negara Indonesia Tbk

\begin{tabular}{cc}
\hline Tahun & GPM \\
\hline 2014 & $59 \%$ \\
2015 & $45 \%$ \\
2016 & $48 \%$ \\
2017 & $54 \%$ \\
2018 & $56 \%$ \\
\hline Rata-rata & $\mathbf{5 2 \%}$ \\
\hline
\end{tabular}

Sumber : Data Hasil Olahan

Dapat dilihat dari tabel diatas bahwa jumlah presentase GPM terjadi turun naik dari tahun ke tahun dengan jumlah rata-rata $52 \%$ 
Tabel 2. Deskripsi Data Operating Profit Margin (OPM) terhadap Laporan Keuangan PT. Bank Negara Indonesia Tbk.

\begin{tabular}{cc}
\hline Tahun & OPM \\
\hline 2014 & $59 \%$ \\
2015 & $45 \%$ \\
2016 & $48 \%$ \\
2017 & $54 \%$ \\
2018 & $55 \%$ \\
\hline Rata-rata & $\mathbf{5 2 \%}$ \\
\hline
\end{tabular}

Sumber : Data Hasil Olahan

Dapat dilihat dari tabel diatas bahwa jumlah presentase OPM terjadi turun naik dari tahun ke tahun dengan jumlah rata-rata $52 \%$

Tabel 3. Deskripsi Data Net Profit Margin (NPM) terhadap Laporan Keuangan PT. Bank Negara Indonesia Tbk.

\begin{tabular}{cc}
\hline Tahun & NPM \\
\hline 2014 & $48 \%$ \\
2015 & $36 \%$ \\
2016 & $38 \%$ \\
2017 & $43 \%$ \\
2018 & $42 \%$ \\
\hline Rata-rata & $\mathbf{4 1 \%}$ \\
\hline
\end{tabular}

Sumber : Data Hasil Olahan

Dapat dilihat dari tabel diatas bahwa jumlah presentase NPM terjadi turun naik dari tahun ke tahun dengan jumlah rata-rata $41 \%$

Tabel 4. Deskripsi Data Return On Assets (ROA) terhadap Laporan Keuangan PT. Bank Negara Indonesia Tbk.

\begin{tabular}{cc}
\hline Tahun & ROA \\
\hline 2014 & $3 \%$ \\
2015 & $2 \%$ \\
2016 & $2 \%$ \\
2017 & $2 \%$ \\
2018 & $2 \%$ \\
\hline
\end{tabular}

\begin{tabular}{c}
\hline Rata-rata \\
\hline
\end{tabular}

Sumber : Data Hasil Olahan

Dapat dilihat dari tabel diatas bahwa jumlah presentase ROA terjadi penurunan dari tahun ke tahun dengan jumlah rata-rata $2 \%$

Tabel 5. Deskripsi Data Return On Equity (ROE) terhadap Laporan Keuangan PT. Bank Negara Indonesia Tbk.

\begin{tabular}{cc}
\hline Tahun & ROE \\
\hline 2014 & $18 \%$ \\
2015 & $12 \%$ \\
2016 & $13 \%$ \\
2017 & $14 \%$ \\
2018 & $14 \%$ \\
\hline Rata-rata & $\mathbf{1 4 \%}$
\end{tabular}

Sumber : Data Hasil Olahan

Dapat dilihat dari tabel diatas bahwa jumlah presentase ROE terjadi turun naik dari tahun ke tahun dengan jumlah rata-rata $14 \%$.

\section{Pembahasan}

Dari hasil perhitungan diatas dapat disimpulkan sebagai berikut :

1. Gross Profit Margin (GPM)

Berdasarkan penjelasan diatas dapat disimpulkan bahwa tingkat Gross Profit Margin selama lima tahun berjalan dalam keadaan "baik" karena memenuhi standar industri yang ditetapkan.

\section{Operating Profit Margin (OPM)}

Berdasarkan penjelasan diatas dapat disimpulkan bahwa tingkat Operating Profit Margin selama lima tahun berjalan dalam 
keadaan "baik" karena memenuhi standar industri yang ditetapkan.

\section{Net Profit Margin (NPM)}

Berdasarkan penjelasan diatas dapat disimpulkan bahwa tingkat Net Profit Margin selama lima tahun berjalan dalam keadaan "baik" karena memenuhi standar industri yang ditetapkan.

\section{Return on Assets (ROA)}

Berdasarkan penjelasan diatas dapat disimpulkan bahwa tingkat Return on Assets selama lima tahun berjalan dalam keadaan "kurang baik" karena belum memenuhi standar industri yang ditetapkan.

\section{Return on Equity (ROE)}

Berdasarkan penjelasan diatas dapat disimpulkan bahwa tingkat Return on Equity selama lima tahun berjalan dalam keadaan "kurang baik" karena belum memenuhi standar industri yang ditetapkan.

\section{Kesimpulan}

Berdasarkan hasil analisis dari data dengan menggunakan metode analisis rasio profitabilitas pada PT Bank Negara Indonesia Tbk cabang manado, maka dapat diambil kesimpulan sebagai berikut:

\section{Rasio profitabilitas merupakan rasio} yang digunakan untuk mengukur kemampuan perusahaan dalam menghasilkan laba dari aktivitas normal bisnisnya. Dengan indikator yang ada dalam rasio profitabilitas yaitu GPM, OPM,
NPM, ROA, ROE. Dapat disimpulkan dari semua indikator terdapat tiga indikator yang dapat dikatakan "baik" karena berada diatas standar industri, dan juga terdapat dua indikator yang dikatakan "kurang baik" karena masih di bawah standar industri.

\section{Saran}

Berdasarkan hasil analisis, maka perlu juga diberikan saran berdasarkan kesimpulan diatas. Dalam kesimpulan diatas penulis menyimpulkan terdapat dua indikator dalam rasio profitabilitas yang belum mencapai standar industry yaitu:

Return on Assets dan Return on Equity, maka dari itu saran yang dapat diberikan adalah untuk meningkatkan dua indikator dalam rasio profitabilitas yang belum memenuhi standar industri perusahaan harus mengontrol dan memperhatikan setiap kegiatan operasional agar perusahaan dapat menggunakan analisis profitabilitas dengan sebaik mungkin. Dan juga harus memperhatikan hal-hal penting yang diperlukan perusahaan dalam meningkatkan keuntungan.

\section{Daftar Pustaka}

Astrinika L. Agustin, Darminto, dan Siti R. Handayani. 2013. Analisis Rasio Keuangan Untuk menilai kinerja keuangan perusahaan. Jurnal Administrasi Bisnis (JAB). Vol 2 Nol 
Kasmir. 2015. Analisis Laporan Keuangan. Jakarta. PT Raja Grafindo Persada

Jumingan. 2014. Analisis Laporan Keuangan. Jakarta, PT Bumi Aksara

Kasmir. 2014. Dasar-dasar Perbankan. Depok, PT Raja grafindo Persada

Hijriyani, Nur Zulfah, Setiawan. 2017. Analisis Profitabilitas Perbankan Syariah di Indonesia Sebagai Dampak dari Efisiensi Operasional. Jurnal Kajian Akuntansi. Vol 1, No 2

Irham Fahmi. 2014. Analisis Kinerja Keuangan Panduan bagi akademisis, Manajer, dan Investor Untuk Menilai dan Menganalisis Bisnis dari Aspek Keuangan. Bandung, Alfabeta, CV

Nurbaiti, Farida Lena. 2016. Analisis Rasio Profitabilitas untuk Mengukur Kinerja Keuangan Pada Bank BUMN Yang Terdaftar di Bursa Efek Indonesia Periode 2010-2014. Jurnal Online Mahasiswa (JOM) Bidang Ilmu Sosial dan Ilmu Politik. Vol 3, No 2

Sofyan S. Harahap. 2016. Analisis Kritis Terhadap Laporan Keuangan. Jakarta, PT RajaGrafindo Persada

Yusa, Feby Febrianti, Ruzikna. 2016. Analisis Rasio Likuiditas dan Rasio Profitabilitas dalam Rangka Meningkatkan Kinerja Keuangan (kasus pada perusaaan kosmetik dan barang keperluan rumah tangga yang terdaftar di Bursa Efek Indonesia). Jurnal Online Mahasiswa (JOM) Bidang Ilmu Sosial dan Ilmu Politik. Vol 3, No 2 